\title{
Drilling the North Anatolian Fault
}

by Georg Dresen, Mustafa Aktar, Marco Bohnhoff, and Haluk Eyidogan

The North Anatolian Fault Zone (NAFZ) represents a $\sim 1400$-km-long plate boundary that slips at an average rate of 20-30 mm yr-1. It separates the westward moving Anatolian block in the south from Eurasia in the north (McClusky et al., 2000). Comparison of long-term slip rates $\left(6.5 \mathrm{~mm} \mathrm{yr}^{-1}\right.$ for the last $13 \mathrm{Ma}, 17 \mathrm{~mm} \mathrm{yr}^{-1}$ for the last $5 \mathrm{Ma}$,) with Holocene and GPS-derived slip rates (20-25 $\mathrm{mm} \mathrm{yr}^{-1}$ ) indicate an accelerated movement in the recent geological past. During the twentieth century, the NAFZ has ruptured over $900 \mathrm{~km}$ of its length. A series of large earthquakes starting in 1939 near Erzincan in eastern Anatolia propagated westward towards the Istanbul-Marmara region in northwestern Turkey. A large part of the Sea of Marmara today represents a seismic gap along a $\geq 100$-km-long segment which did not rupture since 1766 and may have accumulated a slip deficit of 4-5 m. It is believed to be capable of generating two $M \geq 7.1$ earthquakes within the next decades or could even rupture in a large single event.

The most recent devastating earthquakes in the region occurred in 1999 near Izmit and Düzce with magnitudes greater than 7 . Their western termination of rupture is located offshore below the eastern Sea of Marmara possibly extending to just south of the Princes Islands within $\sim 20 \mathrm{~km}$ of Istanbul (Fig.1).

Below the Sea of Marmara, the NAFZ branches in two prominent offshore fault segments (Fig. 1) that bound a pullapart depocenter (Cinarcik Basin) in the $\mathrm{NE}$ and $\mathrm{SE}$ containing $16-20 \mathrm{~mm} \mathrm{yr}^{-1}$ GPS-derived surface displacement at present. The NAFZ is again exposed on the western

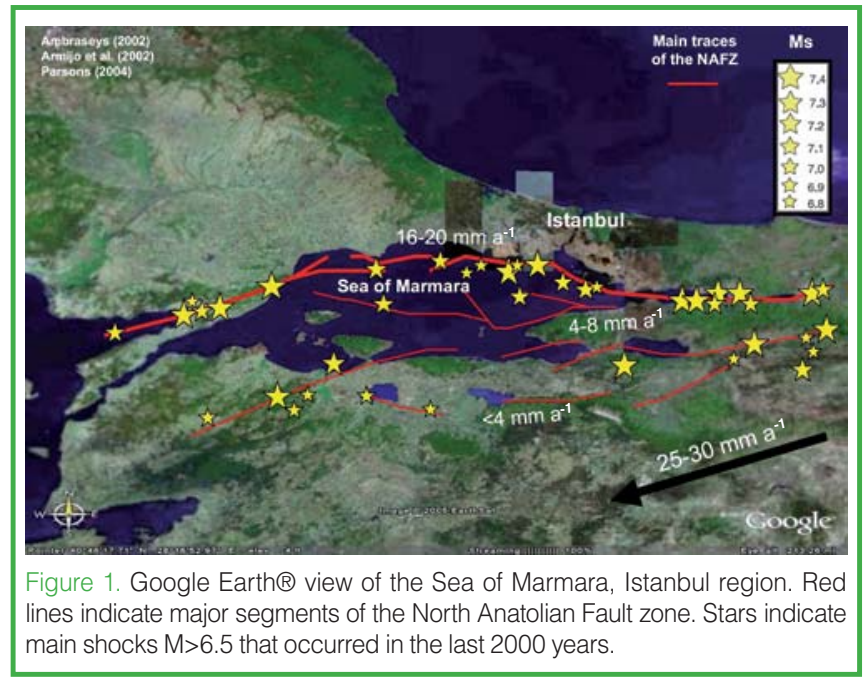

Dardanelles Peninsula merging with the Ganos Fault. Here, the last $\mathrm{M}>7$ earthquake occurred in 1912 rupturing approximately $60 \mathrm{~km}$ into the Sea of Marmara.

In the eastern Sea of Marmara, five seismic events with $M>6$ have occurred since 1509. The events in 1509, 1754, 1766, and 1894 generated tsunamis with waves exceeding $6 \mathrm{~m}$ in height in some cases. Also, the 1999 Izmit earthquake, reflecting pure strike-slip faulting, generated a minor tsunami with local wave heights $>2 \mathrm{~m}$.

Current seismic activity in the eastern Marmara Sea indicates the seismic gap south of Istanbul and a complex fault network active at the transition between the western end of the Izmit earthquake rupture (Fig. 2; Aktar et al., 2004; Karabulut et al., 2002). The majority of focal mechanism solutions indicate dominant strike-slip motion with minor normal faulting activity; however, existing seismicity images of the region lack the spatial and temporal resolution required for an accurate definition of seismic versus aseismic zones. This is due to the magnitude threshold of the existing seismic networks that is currently limited to about magnitude 2 .

Our knowledge of the stress state at the NAFZ is rudimentary (Heidbach et al., 2004). Stress orientation with respect to the fault zone as given in the World Stress Map is mainly based on a small number of focal mechanisms of larger seismic events. Maximum compressive stress is generally oriented at $35^{\circ}-45^{\circ}$ with respect to the fault trend, so the NAFZ does not appear to be a weak fault in contrast to other major plate bounding faults. No data exist on stress magnitudes and on heat flow close to the NAFZ for the entire Marmara Sea area.

Positive Coulomb stress changes in the Marmara region suggest that the Izmit earthquake significantly increased the seismic hazard for the Istanbul-Marmara region. The Izmit event has increased the 2004-2034 probability for an earthquake $\mathrm{M} \geq 7$ by 2-6 times. Estimated thirty-year probability for an event $\mathrm{M} \geq 7$ is 35\%-70\% (Parsons., 2004; Parsons et al., 2000; Wright et al., 2001).

We currently investigate aftershock focal mechanisms of the Mw=7.4 Izmit earthquake of 17 August 1999, on the western North Anatolian Fault Zone (Bohnhoff et al., 2006). Spatial clustering and orientation of 446 fault plane solutions were analyzed. Aftershock clusters define four individual 


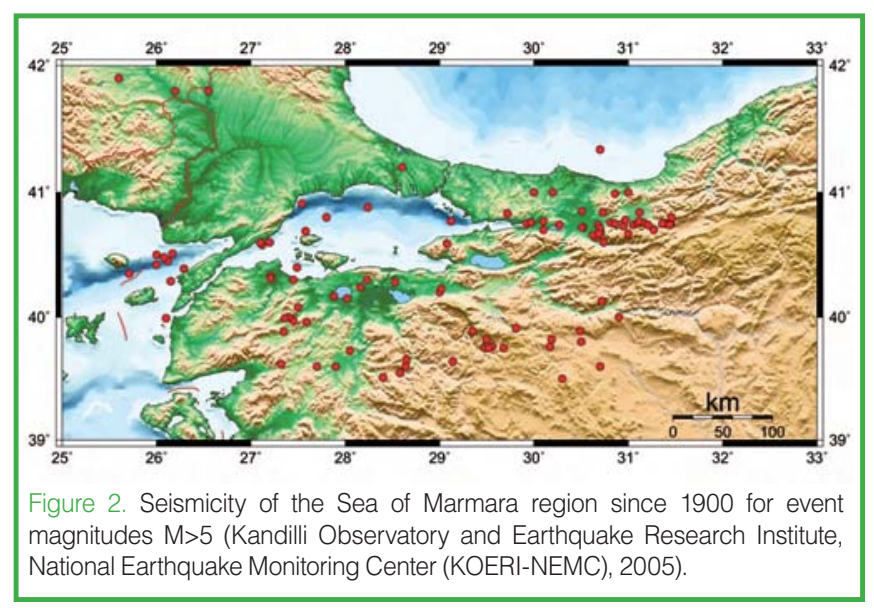

fault segments. The distribution of aftershock focal mechanisms corresponds to fault segmentation of the NAFZ in the Izmit-Düzce region produced by coseismic slip. Areas with high coseismic slip show aftershocks that are dominantly strike-slip, but low-slip barriers show mostly normal faulting aftershocks.

Focal mechanisms surrounding epicenters of the Izmit and subsequent Düzce main shock (Mw=7.1, 12 November 1999) indicate dominantly strike-slip but also normal faulting. Below the easternmost portion of the Sea of Marmara, alignments of aftershocks suggest branching of the NAFZ into three or more active segments that differ significantly in orientation of focal mechanisms.

Stress tensor inversions of the aftershock focal mechanisms show systematic rotations of the local stresses following the Izmit main shock. We conclude that the Izmit earthquake caused significant stress partitioning along the rupture. The direction of stress rotation is related to the orientation of the individual fault segments along the NAFZ.

We propose to drill a deep borehole close to the main branch of the NAFZ on the outermost Princes Islands close to the Istanbul metropolitan region and to install a multipa- rameter deep borehole observatory (Fig. 3). Regarding recent seismic activity, the Princes Islands are located on a transition between the western end of the Izmit rupture and a fault segment showing very low activity, suggesting that this part of the fault is currently locked.

The deep-borehole observatory will allow an enhanced monitoring of microseismic activity, stress, heat and fluid flow near the NAFZ. The location of the observatory represents the only possible long-term monitoring site of seismic activity in the vicinity of Istanbul, and it is located at a NAFZ segment that is considered a seismic gap. Owing to postseismic stress redistribution after the Izmit earthquake, the area is likely subjected to enhanced stresses.

The observatory will be installed at the bottom of a 2000-m-deep vertical borehole. The vertical seismometer array will be combined with an array of seismometers in shallow boreholes. A deep borehole observatory will permit observing earthquake activity close to the seismically active region of the fault zone at a depth between $4 \mathrm{~km}$ and $15 \mathrm{~km}$. A chain of borehole seismometers will enhance the accuracy of hypocenter determinations and significantly decrease the magnitude-detection threshold. This would allow studying the rupture process of small-magnitude earthquakes close to their source region in unprecedented detail.

The orientation and magnitude of local stresses and strains at the fault and their change with depth can be determined. This will assist estimating the in situ strength of a major plate boundary fault. Fluid pressures in close proximity to active fault strands of the NAFZ will be monitored. The proposed borehole observatory will allow us to address the following fundamental problems, partly in combination of with a shallow borehole array and offshore campaign measurements:

- Is the North Anatolian Fault Zone in northwestern Turkey a weak or a strong plate boundary?

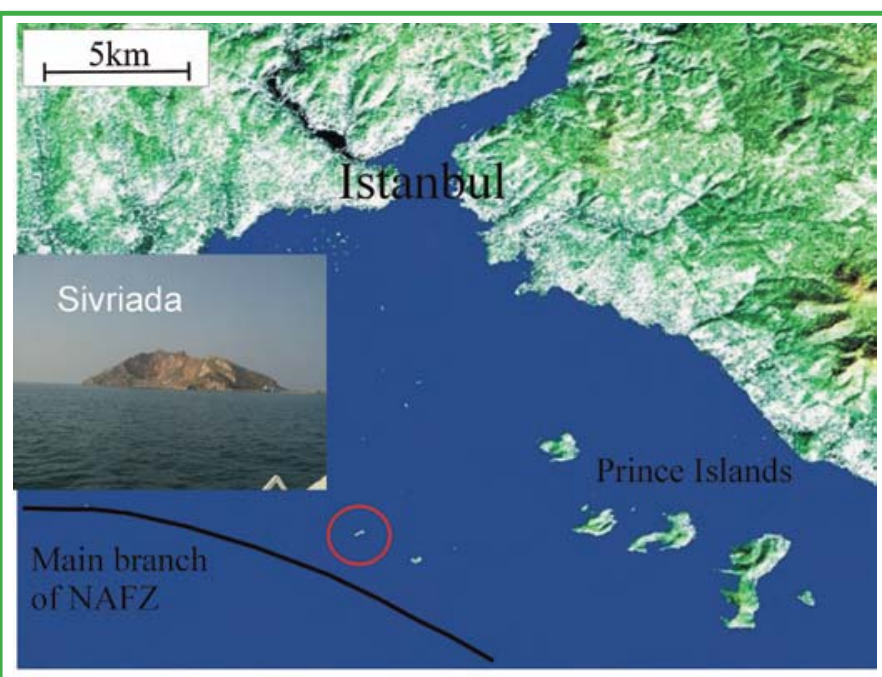

Proposed location for a deep drill hole

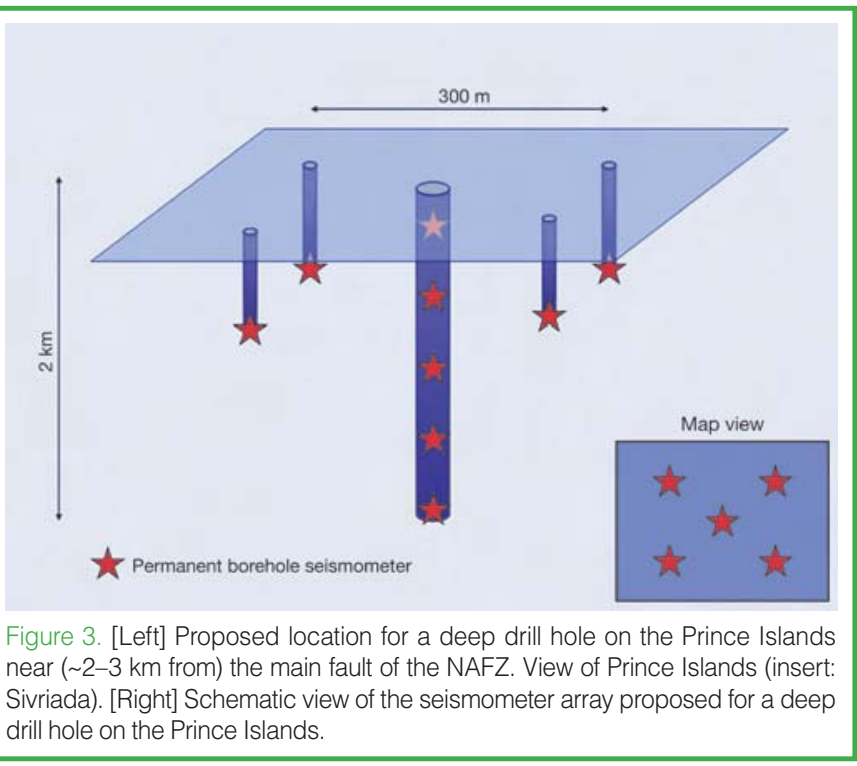


- What is the orientation of the principal stresses at the fault zone? Do stresses at the fault zone vary with depth and time?

- How does the structural heterogeneity of the fault affect the earthquake nucleation process?

- How is the dynamic propagation of a shear rupture affected by the fault structure?

- How is deformation partitioned between aseismic creep and seismic slip at the termination of a major earthquake rupture?

- What is the continuation of the faults at depth? Is there a deep-seated master fault in the Sea of Marmara south of Istanbul?

Currently, discussion of fault kinematics in the Marmara segment of the NAFZ has been controversial (Armijo et al., 2002, 2005; Le Pichon et al., 2001, 2003). Fault kinematics have important consequences for the seismic hazard assessment pertinent to the Istanbul area. For example, Armijo et al. (2005) suggested a maximum seismic risk for a well defined 70-100-km-long fault segment between the 1912 and 1999 ruptures where a slip deficit of 4-5 m might have accumulated (this is capable of generating a $\mathrm{M} \sim 7$ event). This is in agreement with recurrence intervals of 270 years for this region with regard to the 1766 event. Other studies suggest that the fault is less segmented and might rupture through its entire length of up to $150 \mathrm{~km}$. The proposed deep-borehole geophysical observatory close to the NAFZ will permit us to examine some of the key questions pertinent to faulting activity and earthquake mechanics in general and seismic hazard assessment for the Istanbul area in particular.

\section{References}

Aktar, M., Özalaybey, S., Ergin, M., Karabulut, H., Bouin, M.P., Tapýrdamaz, C., Biçmen, F., Yörük, A., and Bouchon, M., 2004. Fault zone heterogeneity and variations of seismicity parameters across 1999 Ýzmit-Düzce earthquake sequence. Tectonophysics, 391:325-334, doi:10.1016/j. tecto.2004.07.020.

Ambraseys, N., 2002. The seismic activity of the marmara sea region over the last 2000 years. Bull. Seismol. Soc. Am., 92:1:1-18, doi:10.1785/0120000843.

Armijo, R., Meyer, B., Navarro, S., King, G., and Barka, A., 2002. Asymmetric slip partitioning in the Sea of Marmara pullapart: Aclue to propagation processes of the North Anatolian fault? Terra Nova, 14(2):80-86, doi:10.1046/j.13653121.2002.00397.x.

Armijo, R., Pondard, N., Meyer, B., Uçarkus, G., Mercier de Lépinay, B., Malavieille, J., Dominguez, S., Gustcher, M.-A., Schmidt, S., Beck, C., Çagatay, N., Çakir, Z., Imren, C., Eris, K., Natalin, B., Özalaybey, S., Tolun, L., Lèfevre, I., Seeber, L., Gasperini, L., Rangin, C., Emre, O., and Sarikavak, K., 2005. Submarine fault scarps in the Sea of Marmara pull-apart (North Anatolian fault): Implications for seismic hazard in
Istanbul. Geochem. Geophys. Geosyst., 6(6):Q06009, doi:10.1029/2004GC000896.

Bohnhoff, M., Grosser, H., and Dresen, G., 2006. Strain partitioning and stress rotation at the North Anatolian fault zone from aftershock focal mechanisms of the 1999 Izmit $\mathrm{Mw}=7.4$ earthquake. Geophys. J. Int., in press.

Heidbach, O., Barth, A., Connolly, P., Fuchs, F., Müller, B., Reinecker, J., Sperner, B., Tingay, M., and Wenzel, F., 2004. Stress maps in a minute: The 2004 world stress map release. Eos Trans., 85(49):521-529.

Karabulut, H., Bouin, M.-P., Bouchon, M., Dietrich, M., Cornou, C., and Aktar, M., 2002. The seismicity in the Eastern Marmara Sea after the 17 August 1999 Izmit Earthquake. Bull. Seismol. Soc. Am., 92(1):387-393, doi:10.1785/0120000820.

LePichon, X., Pengör, A.M.C., Demirbað, E., Rangin, C., Ýmren, C., Armijo, R., Görür, N., Çaðatay, N., Mercier de Lepinay, B., Meyer, B., Saatçýlar, R., and Tok, B., 2001. The active Main Marmara Fault. Earth Planet. Sci. Lett., 192:595-616, doi:10.1029/2002JB001862.

LePichon, X., Chamot-Rooke, N., Rangin, C. and Sengör, A.M.C., 2003. The North Anatolian fault in the Sea of Marmara. J. Geophys. Res., 108(B4):2179, doi: 10.1029/2002JB001862.

McClusky, S., Balassanian, S., Barka, A., Demir, C., Ergintav, S., Georgiev, I., Gurkan, O., Hamburger, M., Hurst, K., Kahle, H., Kastens, K., Kekelidze, G., King, R., Kotzev, V., Lenk, O., Mahmoud, S., Mishin, A., Nadariya, M., Ouzounis, A., Paradissis, D., Peter, Y., Prilepin, M., Reilinger, R., Sanli, I., Seeger, H., Tealeb, A., Toksöz, M.N., and Veis, G., 2000. Global positioning system constraints on plate kinematics and dynamics in the eastern Mediterranean and Caucasus, J. Geophys. Res., 105:5695-5719, doi:10.1029/ 1999JB900351.

Parsons, T., 2004. Recalculated probability of $M \geq 7$ earthquakes beneath the Sea of Marmara, Turkey. J. Geophys. Res., 109: B05304, doi:10.1029/2003JB002667.

Parsons, T., Toda, S., Stein, R.S., Barka, A., and Dieterich, J.H., 2000. Heightened odds of large earthquakes near Istanbul: An interaction-based probability calculation. Science, 288:661664, doi:10.1126/science.288.5466.661.

Wright, T., Fielding, E., and Parsons, B., 2001. Triggered slip: observations of the 17 August 1999 Izmit (Turkey) earthquake using radar interferometry. Geophys. Res. Lett., 28(6):10791082, doi:10.1029/2000GL011776.

\section{Authors}

Georg Dresen, GeoForschungsZentrum Potsdam, Sektion 3.2 Deformaton und Rheologie, Telegrafenberg, D-14473, Potsdam, Germany, e-mail: dre@gfz-potsdam.de.

Mustafa Aktar, Bogazici University, Kandilli Observatory and Earthquake Research Institute (KOERI), Cangelkoy, Istanbul, 81220, Turkey.

Marco Bohnhoff, GeoForschungsZentrum Potsdam, Haus D, Projectbereich 3.2, Telegrafenberg, D-14473, Potsdam, Germany.

Haluk Eyidogan, Istanbul Technical University, Mining Faculty, Department of Geophysics, 34469, Maslak, Istanbul, Turkey. 